\title{
Opportunities to catalyze improved healthcare access in pluralistic systems: a cross-sectional study in Haiti
}

\section{Authors}

Molly B Klarman ${ }^{1 \dagger}$, Justin Schon ${ }^{2,3^{*} \dagger}$, Youseline Cajusma ${ }^{1}$, Stace Maples ${ }^{4}$, Valery M Beau de Rochars $^{5}$, Chantale Baril ${ }^{6}$, Eric J Nelson ${ }^{1}$

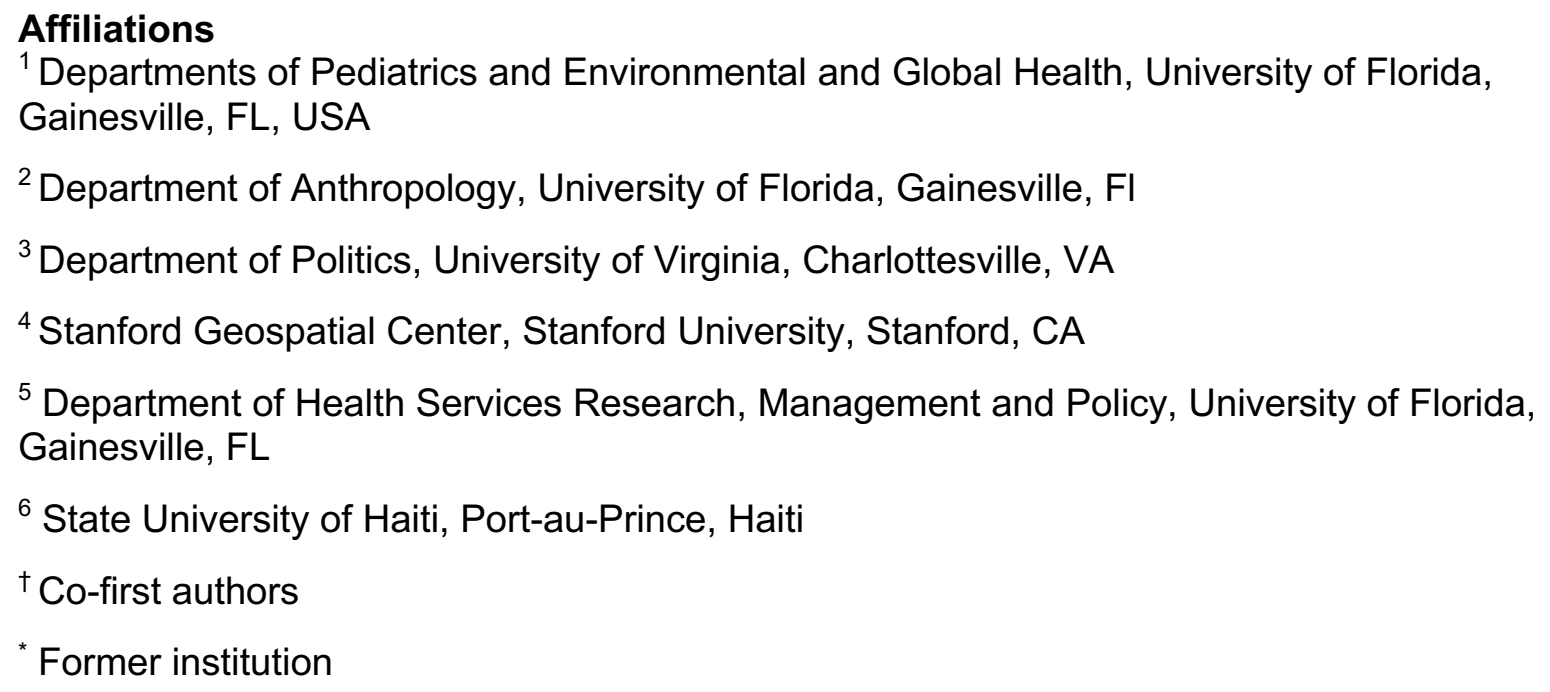

\section{Corresponding author contact information}

Eric J. Nelson, MD PhD

2055 Mowry Road, Emerging Pathogens Institute, University of Florida

Gainesville, FL 32611

Email: eric.nelson@ufl.edu 
medRxiv preprint doi: https://doi.org/10.1101/2020.12.03.20243394; this version posted May 7, 2021. The copyright holder for this preprint (which was not certified by peer review) is the author/funder, who has granted medRxiv a license to display the preprint in perpetuity. It is made available under a CC-BY-NC-ND 4.0 International license .

\section{SUMMARY}

Introduction. Gains to ensure global healthcare access are at risk of stalling because some old resilient challenges require new solutions. Our objective was to study a pluralistic healthcare system that is reliant on both conventional and non-conventional providers to discover opportunities to catalyze renewed progress.

Methods. A cross-sectional study was conducted among households with children less than 5 years of age in Haiti. Households were randomly sampled geographically with stratifications for population density. Household questionnaires with standardized cases (intentions) were compared to self-recall of health events (behaviors). The connectedness of households and their providers was determined by network analysis. Results. A total of 568 households (incorporating 2900 members) and 65 providers were enrolled. Households reported 636 health events in the prior month. Households sought care for $35 \%(n=220)$ and treated with home remedies for $44 \%(n=277)$. The odds of seeking care increased $217 \%$ for severe events (aOR=3.17; $95 \% \mathrm{Cl} 1.99-5.05$; $p<0.001$ ). The odds of seeking care from a conventional provider increased by $37 \%$ with increasing distance $(a O R=1.37 ; 95 \% \mathrm{Cl} 1.06-1.79 ; p=0.016)$. Despite stating an intention to seek care from conventional providers, there was a lack of congruence in practice that favored non-conventional providers (McNemar's Chi-squared Test $p<0.001)$. Care was sought from primary providers for $68 \%(n=150)$ of cases within a three-tiered network; 25\% ( $n=38 / 150)$ were non-conventional.

Conclusion. Addressing geographic barriers, possibly with technology solutions, should be prioritized to meet healthcare seeking intentions while developing approaches to connect non-conventional providers into healthcare networks when geographic barriers cannot be overcome. 
medRxiv preprint doi: https://doi.org/10.1101/2020.12.03.20243394; this version posted May 7, 2021. The copyright holder for this preprint (which was not certified by peer review) is the author/funder, who has granted medRxiv a license to display the preprint in perpetuity. It is made available under a CC-BY-NC-ND 4.0 International license.

\section{Article Summary}

- The study is inclusive of both conventional and non-conventional healthcare providers, reflecting Haiti's pluralistic healthcare system.

- $\quad$ The study utilized randomized geospatial sampling method to ensure participants were geographically representative of all families in the study area.

- $\quad$ Employed an unique application of network analysis to observe relationships between families and healthcare providers to identify approaches to increase healthcare access in seemingly change resilient pluralistic systems.

- A limitation of the approach to compare healthcare seeking intentions and behaviors was that the standardized case scenarios did not cover all health event scenarios.

- A limitation on enrollment was that non-conventional healthcare providers were more difficult to locate than conventional providers. 
medRxiv preprint doi: https://doi.org/10.1101/2020.12.03.20243394; this version posted May 7, 2021. The copyright holder for this preprint (which was not certified by peer review) is the author/funder, who has granted medRxiv a license to display the preprint in perpetuity. It is made available under a CC-BY-NC-ND 4.0 International license .

\section{INTRODUCTION}

3 Improving access to healthcare is one of the highest global health priorities set by the

4 Sustainable Development Goals (SDG) (2015)ํ. SDG 3.8 seeks to "achieve universal

5 health coverage (UHC)", however the current rate of progress is insufficient to reach this target by 2030. Low and middle income countries (LMIC) are the furthest off track ${ }^{2}$,

7 and UHC tracking indicators show no significant gains for children between 2010 and

$82020^{4}$. The COVID-19 pandemic will exacerbate the limited progress ${ }^{5}$. Innovative

9 approaches are needed to overcome resilient barriers to catalyze progress to achieve 10 universal healthcare access.

11 Common barriers are accessibility, availability, and acceptability ${ }^{6}$. Determinants inside and outside of households influence when a potential barrier manifests as an actual barrier. One method to prioritize determinants for action is to investigate healthcare seeking behaviors starting with illness recognition ('is the family member sick?') and response ('what should the family do?'). Determinants associated with 'recognition' and 'response' include biomedical understanding of illness ${ }^{7}$, ability to recognize danger signs $^{8}$, caregiver's perception of illness severity ${ }^{9-11}$, age ${ }^{12}$, level of education ${ }^{7}$ and marriage status ${ }^{11}$, number of symptoms ${ }^{11}$, gender ${ }^{13}{ }^{14}$, rural/urban location ${ }^{715}$, intra-

19 household relationships ${ }^{1617}$, distance ${ }^{151819}$, finances 171920 and wait times ${ }^{18}$.

Once a decision is made to seek care, factors that influence provider selection reveal additional barriers. LMIC healthcare systems are poorly defined with a range of conventional and non-conventional providers; alternative terminologies are

23 qualified/unqualified or formal/informal ${ }^{21}$. Parallel and differential access to conventional 24 and non-conventional providers manifests in chaotic systems ${ }^{22}$. Conventional providers 25 can be defined as licensed doctors and nurse practitioners at government or non- 
medRxiv preprint doi: https://doi.org/10.1101/2020.12.03.20243394; this version posted May 7, 2021. The copyright holder for this preprint (which was not certified by peer review) is the author/funder, who has granted medRxiv a license to display the preprint in perpetuity. It is made available under a CC-BY-NC-ND 4.0 International license .

governmental organization (NGO) facilities. Non-conventional providers can be defined as traditional healers, medication vendors, unlicensed practitioners and pharmacists.

Provider selection exposes conflicts between a patient's intention ('would do') and behavior ('did do')23 24 . These conflicts represent an opportunity to reveal unanticipated solutions to improve access to care.

The associated networks within pluralistic healthcare systems rely on the relationships among and between conventional and non-conventional providers ${ }^{25}{ }^{26}$. Conventional primary care providers, including community health workers, are assumed to be the first access point into healthcare systems ${ }^{27}$, however non-conventional providers have an important and underappreciated role ${ }^{28}$. Non-conventional providers often practice in parallel without disclosure to conventional providers which creates alternative pathways for seeking care ${ }^{29}$. These complex relationships are not adequately understood, yet are essential to improving healthcare access ${ }^{30-32}$.

Haiti was chosen as a generalizable setting to address these knowledge gaps. Access to healthcare in Haiti is low at $23 \%$ nationwide and $5 \%$ among the rural population ${ }^{33}$.

41 Non-conventional healthcare services and traditional medicine are common ${ }^{32}{ }^{34-36}$. Child 42 health and wellness is substandard with Haiti ranking 150 out of 180 countries $^{37}$. The under five year mortality rate is $67 / 1,000$ live births compared to $41 / 1,000$ live births globally ${ }^{38}$. Healthcare seeking behavior in Haiti has been evaluated for mental health ${ }^{39}$, prenatal care ${ }^{40}$, childbirth location ${ }^{41}$ and $\operatorname{cost}^{42}{ }^{43}$. Our objective was to address

47 behavior and provider selection from conventional and non-conventional providers, and 
medRxiv preprint doi: https://doi.org/10.1101/2020.12.03.20243394; this version posted May 7, 2021. The copyright holder for this preprint (which was not certified by peer review) is the author/funder, who has granted medRxiv a license to display the preprint in perpetuity. It is made available under a CC-BY-NC-ND 4.0 International license .

\section{METHODS}

Study design and participants. In this cross-sectional study, consenting participants were enrolled at the household and healthcare provider levels. Household inclusion criteria were households with an adult (18 years or older) head-of-household $(\mathrm{HoH})$ and at least one child under 5 years. Provider inclusion criteria were adult healthcare providers identified by an enrolled household and located within the study area. The 477 sq km study area, encompassing the communes of Gressier and Leogane Haiti, was divided into two-square km grid-cells. Population density was determined by approximating the number of structures within the grid cell using satellite data from the Oak Ridge National Laboratory (USA). Density per grid cell was categorized by structure quartiles; low (0-112 structures), medium (113-397 structures) and high (3984664 structures). Each grid cell was divided into Thiessen polygons using ArcGIS Online (Esri version 18.0.3) with divisions that reflected the number of households targeted for enrollment; low $=18$, medium $=24$, and high $=53$ per grid cell. The first house encountered in a polygon was recruited. Grid-cells were surveyed sequentially (e.g. low, medium, high) and randomly ordered within each category across a 12-month study period (Aug 2018-July 2019). Although ten grid-cells of each density were designated for survey, six of each were sampled because of logistical limitations. Adult participants provided informed written consent. Ethical approvals were obtained from the Comité National de Bioéthique (National Bioethics Committee of Haiti; 1718-35) and the University of Florida (IRB201703246).

Data Collection. Data were collected by one enumerator and one nurse. Survey instruments included two thirty-minute in-person questionnaires administered with REDCap mobile version 9.1.1 and were piloted with non-participant households. A household questionnaire collected demographic and socio-economic data, and 
medRxiv preprint doi: https://doi.org/10.1101/2020.12.03.20243394; this version posted May 7, 2021. The copyright holder for this preprint (which was not certified by peer review) is the author/funder, who has granted medRxiv a license to display the preprint in perpetuity. It is made available under a CC-BY-NC-ND 4.0 International license .

74 healthcare seeking behavior for standardized cases and health events (appendix). A

health event was defined as any illness a household member experienced in the previous month, regardless of whether care was sought. The standardized respiratory and diarrhoeal cases consisted of hypothetical scenarios involving an ill child at 10 PM with typical symptoms of acute respiratory infection or diarrhoea. A provider questionnaire captured details about the facility/business, personnel qualifications and resources available (appendix). Conventional providers were licensed persons who worked at a licensed facility. For large facilities with greater than 200 patients per month, the facility itself was defined as a 'provider'. Non-conventional providers were licensed or non-licensed providers at non-licensed facilities, or mobile non-licensed providers.

Statistical Analysis. Household demographics and health event characteristics were described by proportions for categorical variables and medians with interquartile ranges (IQR) for continuous variables. Social economic status (S.E.S.) index was generated using a summative score of the following components: land, animal, bank account and phone ownership, $\mathrm{HoH}$ education level, household electricity source, fuel source, water source, primary source of income, primary transportation method, sanitation type, household floor, wall and roof type, and grid cell density. Provider characteristics were described similarly. The two primary analyses compared (i) households that did and did not seek care for health events and (ii) households that did and did not seek care from a conventional provider. For care-seeking, we used bivariate and multivariate logistic regression models with seeking care as the dependent variable and expressed the results as odds ratios (ORs) and adjusted odds ratios (aORs) for care sought. Similar methods were used to compare the selection of seeking care from a conventional versus non-conventional provider. Health events were analyzed as discrete variables. 
medRxiv preprint doi: https://doi.org/10.1101/2020.12.03.20243394; this version posted May 7, 2021. The copyright holder for this preprint (which was not certified by peer review) is the author/funder, who has granted medRxiv a license to display the preprint in perpetuity. It is made available under a CC-BY-NC-ND 4.0 International license .

99 Two-mode whole networks 4445 of households and providers compared provider types

100

101

102

103

104

105

106

107

108

109

110

111

112

identified/sought in standardized cases and health events; sub-analyses were

performed for respiratory infection ('cough' or 'cold' with fever), diarrhoeal illness

('diarrhoea' with/without blood), and "other" cases (all other illness types not categorized

as respiratory or diarrhoea). Ego networks ${ }^{44} 46$ were generated for commonly identified

providers in the whole-network analysis. One-mode provider referral networks ${ }^{44}$ were

generated. Statistical significance was defined at $\alpha=0.05$ and $95 \%$ confidence intervals

are provided. Missingness that was not excluded was for provider types identified by

households but not located and enrolled; for regression models, case-wise deletion was

used. Analyses were completed in Stata (v11) and the igraph, and in R (R Foundation

for Statistical Computing; packages included 'sf' by E. Pebesma and R. Bivand 2018) ${ }^{47}$

48.

Patient and public involvement. Patients or the public were not involved in the design, or conduct, or reporting, or dissemination plans of our research.

\section{RESULTS}

Household characteristics. A total of 868 households were randomly screened and $568(65 \%)$ were enrolled with a distribution of 112,144 and 312 between low, medium and high-density grid-cells; $24 \%$ were excluded because the household had no children under 5 years (figure 1A, table 1). The average household had 5.2 members, and among the 2900 household members, $58 \%$ were under 21 years.

Health event characteristics. A total of 636 health events were identified (tables $2, \mathrm{~S} 1, \mathrm{~S} 2) ; 22 \%, 50 \%$, and $28 \%$ of households reported 0,1 , or at least 2 health events in the previous month respectively. The most common symptoms were congestion, fever and cough, present in $61 \%, 52 \%$ and $49 \%$ of health events respectively. The most 
medRxiv preprint doi: https://doi.org/10.1101/2020.12.03.20243394; this version posted May 7, 2021. The copyright holder for this preprint (which was not certified by peer review) is the author/funder, who has granted medRxiv a license to display the preprint in perpetuity. It is made available under a CC-BY-NC-ND 4.0 International license .

123 common perceived cause of health events was humoral pathology ${ }^{49}(41 \%)$, considered

124 an imbalance of 'hot' and 'cold' within the body caused by environmental exposures.

125 Forty percent of health events were considered severe. Half of all health events started at nighttime (55\%), of these, $36 \%$ were severe (table S1). Respiratory infection

127 symptoms started more often at nighttime (66\%) compared to diarrhoea that more often started during the daytime (65\%) (table S2).

Determinants to seek care for health events. Healthcare was sought outside the household for 35\% $(n=220 / 636)$ of health events, and most often for children between 0-4 years $(65 \%)$. The most common reason cited for not seeking care was preference to

132 treat at the household with home remedies $(67 \% ; n=277 / 416)$ followed by the health event did not necessitate treatment (24\%; n=99/416). The majority of households delayed seeking care $(67 \% ; n=138 / 201)$, most commonly citing monetary and transportation (46\%; $n=63 / 138$ ) barriers. Among those who sought care without delay, $68 \%(n=43 / 63)$ chose to do so because of severity. In the bivariate analysis, decreased

137 odds of seeking care was associated with nighttime events $(\mathrm{OR}=0.69 ; 95 \% \mathrm{Cl} 0.50-0.96$; $p=0.029)$ and informal transport $(\mathrm{OR}=0.53 ; 95 \% \mathrm{Cl} 0.36-0.79 ; \mathrm{p}=0.002)$. Increased odds of seeking care were associated with illness severity $(\mathrm{OR}=3.20 ; 95 \% \mathrm{Cl} 2.28-4.50 ; \mathrm{p}<$ 0.001), high density grid-cells $(\mathrm{OR}=1.66 ; 95 \% \mathrm{Cl} 1.18-2.34 ; \mathrm{p}=0.004)$ and high S.E.S. $(\mathrm{OR}=1.45 ; 95 \% \mathrm{Cl} 1.03-2.03 ; p=0.034)$. In the multivariate analysis, the odds of seeking care increased by $217 \%$ with severe illness $(a O R=3.17 ; 95 \% C l$ 1.99-5.05; $p<0.001)$.

144 located and enrolled (figure 1B; table S3). Failure to enroll providers was most

146 inability to locate the provider/ had ceased operation (14\%; $n=19)$. Details from the 147 household surveys enabled the determination of provider type and setting (table S3). 
medRxiv preprint doi: https://doi.org/10.1101/2020.12.03.20243394; this version posted May 7, 2021. The copyright holder for this preprint (which was not certified by peer review) is the author/funder, who has granted medRxiv a license to display the preprint in perpetuity. It is made available under a CC-BY-NC-ND 4.0 International license .

148 Among surveyed providers, 68\% $(n=44)$ had a business license. Variation was observed by grid cell density; only 4 providers were identified in the low-density grid-cells and

150 none were available after 8 pm (table S3).

Determinants to seek care from a conventional provider. Care was sought from a conventional provider for $83 \%(n=180 / 218)$ and a non-conventional provider for $17 \%$ $153(n=38 / 218)$ of health events (table S4). Bivariate analysis found decreased odds of seeking care from a conventional provider was associated with informal transport

$155(\mathrm{OR}=0.33 ; 95 \% \mathrm{Cl} 0.15-0.71 ; \mathrm{p}=0.005)$ and $\mathrm{HoH}$ with no formal education $(\mathrm{OR}=0.32$; $95 \% \mathrm{Cl} 0.12-0.82 ; p=0.018)$. The odds increased in association with S.E.S. $(O R=2.78$; 95\% Cl 1.25-6.25; $p=0.12)$. In multivariate analysis, increased odds of seeking care from a conventional provider was associated with increased travel distance $(\mathrm{aOR}=1.37$; 95\% $\mathrm{Cl} 1.06-1.79 ; \mathrm{p}=0.016)$ and $\mathrm{HoH}$ education at or above secondary school $(a O R=5.00 ; 95 \% \mathrm{Cl} 1.05-25.00 ; p=0.044)$. These findings are consistent with responses that $53 \%$ of families $(n=116 / 220)$ cited distance as the most important factor in provider selection. Households that cited distance traveled a median of $1.5 \mathrm{~km}$ (IQR $0.7 \mathrm{~km}$ $3.9 \mathrm{~km}$ ) in comparison to $3.6 \mathrm{~km}$ (IQR $1.5 \mathrm{~km}-7.8 \mathrm{~km})$ for households that did not cite distance. Households traveled further (Mann Whitney, $p<.0001$ ) to seek care from conventional providers (median 2.6km, IQR 1.1km-5.9km) than non-conventional providers (median $0.9 \mathrm{~km}, \mathrm{IQR} 0.0 \mathrm{~km}-2.3 \mathrm{~km}$ ). The difference in cost was less when

167 households sought care from non-conventional providers (median US \$1.28, IQR US \$0.16-\$2.56) compared to when households sought care from conventional providers

169 (median US \$4.49, IQR US \$1.92-\$7.85; Mann Whitney, $p<0.0001$ ).

\section{Congruence between care seeking intentions and behaviors by provider type.}

171 Comparisons of intentions versus behaviors for the type of provider sought was 
medRxiv preprint doi: https://doi.org/10.1101/2020.12.03.20243394; this version posted May 7, 2021. The copyright holder for this preprint (which was not certified by peer review) is the author/funder, who has granted medRxiv a license to display the preprint in perpetuity. It is made available under a CC-BY-NC-ND 4.0 International license .

173 and the household health events ('where did you go?'). Among all health event types,

174 there was a lack of congruence between intentions and behaviors $(\mathrm{OR}=0.15 ; 95 \% \mathrm{Cl}$

$175 \quad 0.04-0.43 ; p<0.001) ; 27$ of the 31 non-congruent events were attributed to households

176 that intended to seek care from a conventional provider but switched to non-

177 conventional (table S5). In bivariate analysis, ARI with diarrhoea and informal

178 transportation were associated with increased non-congruence. In contrast, $\mathrm{HoH}$

179 education level of secondary and above and high-density grid-cells were associated

180 with congruence. Multivariate analysis found no significant factors (table S6).

Network analysis of care-seeking intentions versus behaviors.

182 Two-mode whole networks were used to evaluate the relationships between households and providers identified through standardized cases and health events (figure 2). The number of households linked to each provider per health event was statistically different compared to standardized respiratory (Mann Whitney, $p=.014$ ) and diarrhoeal (Mann Whitney, $p=.007$ ) cases; distance traveled was statistically different compared to diarrhoeal cases (Wilcoxon, $p=.001$ ); sub-analysis comparisons for respiratory and diarrhoeal specific health events were similar (figure S1). Two-mode ego network analyses focused on a public clinic (C1) and a private hospital (H1) commonly identified in the whole-network analysis as the intended provider (figure 2); in practice, households sought care from these providers less often (Student $t$-test; both $p<0.001$ ).

192 In one-mode analysis, providers identified 33 conventional and 0 non-conventional referral providers that formed a three-tiered network (figure. S2A); 45\% $(n=15)$ received

194 one referral at the lowest tier, $42 \%(n=14)$ received between $2-10$ referrals at the middle tier and $12 \%(n=4)$ received 10 or more referrals at the highest tier. Sixty-eight percent of households sought care from providers receiving zero referrals. Referral networks

197 from standardized respiratory and diarrhoeal cases were similar (figure S2B,C). 
medRxiv preprint doi: https://doi.org/10.1101/2020.12.03.20243394; this version posted May 7, 2021. The copyright holder for this preprint (which was not certified by peer review) is the author/funder, who has granted medRxiv a license to display the preprint in perpetuity. It is made available under a CC-BY-NC-ND 4.0 International license .

\section{DISCUSSION}

Should care be sought, and from whom, are fundamental questions when medical problems arise in households. The decisions may trigger entry into a linear healthcare system with primary, secondary and tertiary conventional providers or a pluralistic system that includes non-conventional providers. In this cross-sectional study, we found that approximately one-third of health events were not treated, one-third were treated at the household and one third sought care. When care was sought, it was for severe illnesses and from a mixture of conventional and non-conventional providers, largely disconnected from healthcare networks, despite intentions to seek care from connected conventional providers. The findings reveal insights on how to catalyze improved healthcare access in seemingly change resilient healthcare settings.

Households living in low population density regions had the lowest S.E.S. compared to those in high population density regions. Households approached health events with a pragmatic mindset aware of healthcare access barriers. Barriers to seeking care included nighttime presentation, limited access to motorized transport, and poverty.

Disease severity was the major determinant to seek care. Families delayed seeking care because of financial and transport barriers, unless the event was severe or not resolving. These data document that poverty and geographic isolation in rural communities are barriers to seek care.

Providers were identified by households in both the standardized cases and the health events. Increased S.E.S correlated with seeking care from a conventional provider. Multivariate analysis identified increased distance, education, and higher population density as correlates of seeking care from a conventional provider. These findings highlight that once a household decides to seek care, poverty and geographic isolation 
medRxiv preprint doi: https://doi.org/10.1101/2020.12.03.20243394; this version posted May 7, 2021. The copyright holder for this preprint (which was not certified by peer review) is the author/funder, who has granted medRxiv a license to display the preprint in perpetuity. It is made available under a CC-BY-NC-ND 4.0 International license .

222 again influence the decision to seek care from a conventional versus non-conventional 223 provider.

224 Intentions ('would do') and behaviors ('did do') for care-seeking and provider selection 225 were compared by analyzing standardized cases against the health events. Conflict 226 between household intentions and behaviors for seeking care from a conventional 227 provider was found. The directionality was from an intention to seek care from a 228 conventional provider to care sought from a non-conventional provider. These analyses highlight the inequity that both poor and geographically isolated households confront

230 between intentions and behaviors. The data also suggest that poor and isolated 231 households are not content with the choice they are forced to make. Network analysis 232 compared intentions versus behaviors for provider selection. A stark contrast was 233 revealed between an intention to seek care from commonly shared providers yet a 234 behavior to seek care from providers that were less commonly shared. For example, 235 networks analysis of two highly desired conventional providers $(\mathrm{C} 1 ; \mathrm{H} 1)$ found that in practice, less care was sought from these providers.

237 Disparity between intentions and behaviors can be found broadly across the domain of 238 healthcare. However, this study provides insight that when faced with poverty and 239 isolation, households are forced to turn to nearby providers that are often nonconventional. Methods to reduce non-congruence between intentions and behaviors are needed. We advocate that governmental and non-governmental organizations develop

242 initiatives to investigate how to link disconnected non-conventional providers into the 243 healthcare networks with conventional providers. In parallel, households may desire and 244 need an innovative alternative mechanism to 'bypass' barriers they face when 245 attempting to seek care from a conventional provider. A new model (figure 3) may 246 include improved access to centralized services, or extending access to/near 
medRxiv preprint doi: https://doi.org/10.1101/2020.12.03.20243394; this version posted May 7, 2021. The copyright holder for this preprint (which was not certified by peer review) is the author/funder, who has granted medRxiv a license to display the preprint in perpetuity. It is made available under a CC-BY-NC-ND 4.0 International license .

247 households by mobile healthcare services either physically or electronically through

248 telemedicine.

249 These findings should be viewed within the context of the study limitations. First, the standardized case questionnaires were designed a priori to investigate the decisionmaking process to seek care for children with respiratory or diarrhoeal disease at night.

252 The analytic strategy to compare standardized cases as intentions and health events as

253 behaviors was established post-hoc. The limitation is that the specific standardized 254 cases were limited to children who developed symptoms at night which reduced the strength of comparison to the diversity of health events despite sub-analysis to compare cases by chief complaint. The sample size of health events with only respiratory or diarrhoeal complaints alone also limited the strength of comparisons with standardized cases. Second, adjustments for household clustering were not performed because $72 \%$ of households had zero or one health event. Third, providers identified by households were difficult to locate and only a portion of providers were located. This resulted in missingness and an information bias such that mobile drug vendors were interviewed less. Lastly, there was a risk of recall bias because questionnaires relied on one-month and one-week recall by households and providers, respectively. Despite these limitations, the approach and findings represent a meaningful contribution.

Conclusion. The study supports a model that households are likely to treat illnesses at home without assistance. When care is sought, it is for severe illnesses and often from

267 a mixture of disconnected conventional and non-conventional providers despite an

268 intention to seek care from a conventional provider. The findings support bridging 269 geographic barriers, possibly with technology solutions, to meet healthcare seeking intentions while developing approaches to connect non-conventional providers into

271 healthcare networks when geographic barriers cannot be overcome. 
medRxiv preprint doi: https://doi.org/10.1101/2020.12.03.20243394; this version posted May 7, 2021. The copyright holder for this preprint (which was not certified by peer review) is the author/funder, who has granted medRxiv a license to display the preprint in perpetuity. It is made available under a CC-BY-NC-ND 4.0 International license .

272 Contributions. EJN and MBK conducted the literature search. The study was designed

273 by EJN and MBK. MBK and CY implemented the study and collected data with

274 guidance from SM. SM provided the approach and tools for geospatial mapping. Data

275 analysis, interpretation, figure design, and writing was conducted by JS, MBK and EJN.

276 Clinical oversight in Haiti was governed by CB with assistance by MVBDR.

277 Communication with IRBs was performed by CB, MVBDR and EJN. IRB documentation was written and managed by MBK and EJN.

Acknowledgements. We thank the households and providers that agreed to participate in this study, and diligent field research team who made this study possible. We are for their support and helpful discussions. We thank M. Gurka, R. Vacca and C. McCarty at the University of Florida for guidance and insight on study design and social network analysis. We also express our gratitude to the Christianville Foundation (Gressier, Haiti) for their shared commitment to healthcare access and providing infrastructure for

286 implementation.

287 Data availability. Data are available in the Supplementary Appendix. [DP5OD019893] to EJN. Internal support was provided by the University of Florida. These funders had no role in the study design, data collection and analysis, decision to publish,

291 or preparation of the manuscript.

292 Disclaimer. These funders had no role in study design, data collection and analysis, 293 decision to publish, or preparation of the manuscript. 
medRxiv preprint doi: https://doi.org/10.1101/2020.12.03.20243394; this version posted May 7, 2021. The copyright holder for this preprint (which was not certified by peer review) is the author/funder, who has granted medRxiv a license to display the preprint in perpetuity. It is made available under a CC-BY-NC-ND 4.0 International license .

To best describe what is known about the subject in this manuscript, we performed two searches in PubMed for reports published after January 1, 2010 in all languages. The first search consisted of the search terms [Haiti] AND [care seeking] OR [health seeking] OR [healthcare seeking]. The criteria identified 16 publications. Four of the articles had a primary focus of healthcare seeking behaviors in Haiti; 1 pertained to rabies, 2 pertained to mental health and 1 pertained to equitable access to healthcare. Care seeking in Haiti was a component in an additional 6 articles, although not as the primary research objective; 1 pertained to rabies, 1 pertained to cholera patients, 1 pertained to suicide, 1 multi-country study pertained to child health and family planning, 1 multicountry study pertained to user fees and 1 multi-country study pertained to malaria and the private health sector. The remaining 6 articles did not pertain to healthcare seeking 307 in Haiti. providers" OR "healthcare provider" OR "referral”. The criteria identified 81 publications. The results were filtered to remove articles with the terms "United States", U.S., Europe, Australia, "neural network analysis", and "thematic network analysis" and non-primary

312 research results were also removed. This yielded 20 publications. Three papers used network analysis to investigate the roll of peer networks, one pertaining to diet and exercise in Korea, one pertaining to risk of migraines in Taiwan, and one pertaining to

315 theoretical support programming for cancer patients. Two papers used network analysis to characterize professional advice seeking behavior; one among physicians in Pakistan

317 and the other among primary healthcare workers in Ethiopia. Three papers used 
medRxiv preprint doi: https://doi.org/10.1101/2020.12.03.20243394; this version posted May 7, 2021. The copyright holder for this preprint (which was not certified by peer review) is the author/funder, who has granted medRxiv a license to display the preprint in perpetuity. It is made available under a CC-BY-NC-ND 4.0 International license .

319 during hospital patient discharge in the US, one pertaining to patient flow in a US

320 hospital and one pertaining to health systems integration in China. One paper created

321 referral networks among community healthcare providers and their patients 65 and

322 older in the United Kingdom to better inform the organization of community services.

323 Another paper from the United Kingdom used network analysis to map and understand

324 naturally occurring communities that could assist in the development of a new primary

325 care network initiative. Three papers examined relationships among networks of

326 organizations who support the health of specific populations, one pertaining to

327 organizations involved in cancer screening of South Asians in Canada, one pertaining to

328 professionals who provide psychosocial care to victims of violence in Colombia, and

329 one pertaining to organizations who address unmet social needs and their clinical

330 partners in the US.

331 Despite this body of literature, we did not identify studies that used original data to

332 investigate general healthcare seeking behavior in Haiti. Beyond Haiti, we did not identify studies that performed a network analysis to investigate relationships between households and the healthcare providers they frequent, especially in a global health

335 context. Referral networks were represented in the literature but in the context of high-

336 income countries. Therefore, the knowledge this manuscript contributes on pluralistic

337 healthcare systems are of great value globally. The innovative methods of leveraging

338 standardized cases to gauge intentions and the network analysis framework benefit

339 teams faced with similar challenges. The study revealed unanticipated opportunities that

340 should be further evaluated outside of Haiti and considered by international

341 stakeholders as avenues to catalyze renewed SDG progress. 
medRxiv preprint doi: https://doi.org/10.1101/2020.12.03.20243394; this version posted May 7, 2021. The copyright holder for this preprint (which was not certified by peer review) is the author/funder, who has granted medRxiv a license to display the preprint in perpetuity. It is made available under a CC-BY-NC-ND 4.0 International license.

\section{FIGURE LEGENDS}

Figure 1. Participant enrollment. A. The study enrolled 568 households representing 2900 household members out of 868 households screened. B. The study enrolled 65 providers out of 140 identified by households using both standardized case and health event questionnaires; percentages are of those identified by households.

Figure 2. Provider selection. Among households with health events in which care was sought ( $n=180)$, two-mode whole network analysis was used to elicit care-seeking intentions for standardized respiratory cases (A), standardized diarrhoeal cases (B), and health events (C). The median number of household-provider linkages per provider and distance traveled were $2(\mathrm{IQR}=1-5)$ and $3.2 \mathrm{~km}(\mathrm{IQR}=1.3 \mathrm{~km}-5.6 \mathrm{~km}), 2.5(\mathrm{IQR}=1-5)$ and $4.0 \mathrm{~km}(\mathrm{IQR}=1.9 \mathrm{~km}-6.4 \mathrm{~km})$ and $1(\mathrm{IQR}=1-2)$ and $2.1 \mathrm{~km}(\mathrm{IQR}=1.0 \mathrm{~km}-5.4 \mathrm{~km})$ for respiratory standardized cases $(A)$, diarrhoeal standardized cases $(B)$ and health events (C), respectively. Ego network analysis of the two most commonly identified providers. Households that selected public clinic $C 1$ in the respiratory standardized case $(n=26$; D), the diarrhoeal standardized case $(n=50 ; E)$, and/or sought care at $\mathrm{C} 1$ for a health event $(n=9 ; \mathbf{F})$. Households that selected private hospital $\mathrm{H} 1$ in the respiratory standardized case $(n=51 ; \mathbf{G})$, the diarrhoeal standardized case $(n=64 ; \mathbf{H})$, and/or sought care at $\mathrm{H} 1$ for a health event $(n=13 ; \mathrm{I})$. 
medRxiv preprint doi: https://doi.org/10.1101/2020.12.03.20243394; this version posted May 7, 2021. The copyright holder for this preprint (which was not certified by peer review) is the author/funder, who has granted medRxiv a license to display the preprint in perpetuity. It is made available under a CC-BY-NC-ND 4.0 International license.

366 Figure 3. Model to improve access to healthcare in a pluralistic system. A. Current

367 relationships between households and providers. B. Opportunities to improve access to

368 care by better connecting households to conventional providers, and non-conventional

369 providers to the healthcare network. Solid gray arrows represent current connections.

370 Dashed green curved arrow represents a bypass mechanism to improve access to

371 conventional primary providers by innovative mechanisms (e.g. dedicated

372 transport/assistance, mobile outreach clinics, telemedicine). Dashed gray arrows

373 represent connections to link conventional/non-conventional providers. 
medRxiv preprint doi: https://doi.org/10.1101/2020.12.03.20243394; this version posted May 7, 2021. The copyright holder for this preprint (which was not certified by peer review) is the author/funder, who has granted medRxiv a license to display the preprint in perpetuity.

\section{It is made available under a CC-BY-NC-ND 4.0 International license .}

\section{Figure 1}

A.

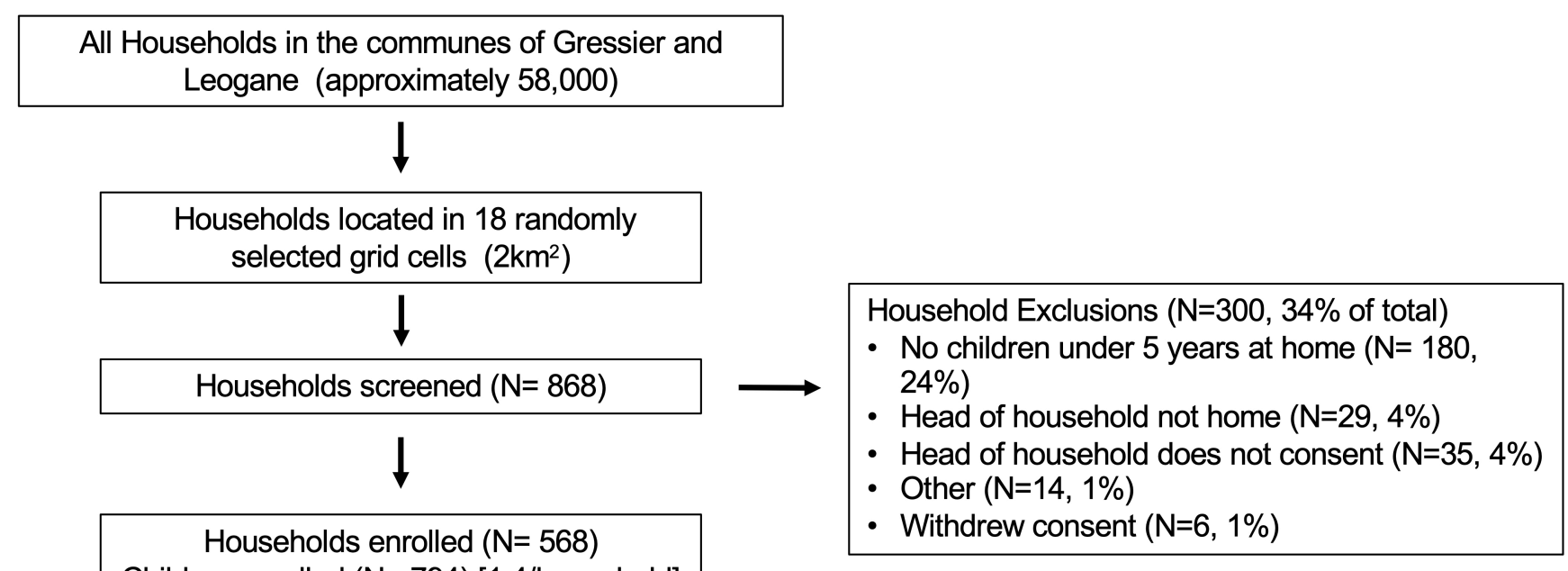

B. Children enrolled $(\mathrm{N}=794)$ [1.4/household]

Unique healthcare providers "identified" during INACT household surveys $(\mathrm{N}=140)$

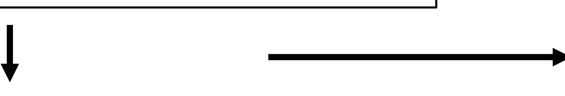

Healthcare providers enrolled $(\mathrm{N}=65)$

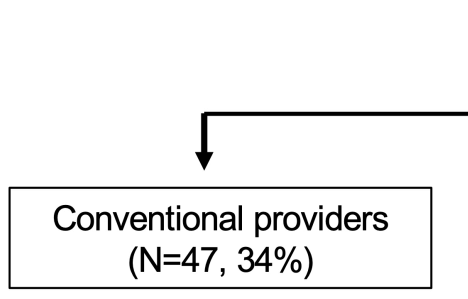

Non-conventional providers $(\mathrm{N}=18,13 \%)$
Provider Exclusions ( $\mathrm{N}=75,54 \%$ of total)

- Outside study area $(\mathrm{N}=29,21 \%)$

- Unable to locate/ closed ( $\mathrm{N}=19,14 \%)$

- Mobile provider ( $\mathrm{N}=14,10 \%)$

- Generic pharmacy/ market stall $(\mathrm{N}=8,6 \%)$

- Decline participation ( $N=5,4 \%)$

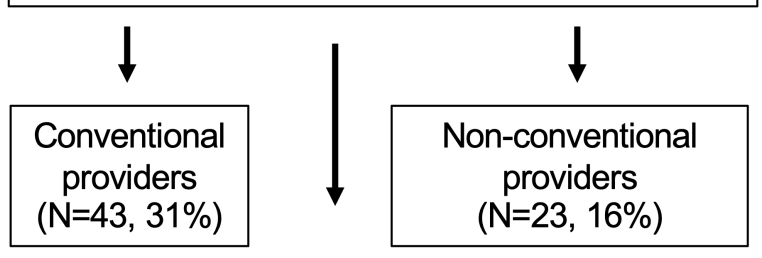

Unknown

$(\mathrm{N}=9,6 \%)$ 


\section{Figure 2}

\section{Standardized Cases (Intentions)}

A.

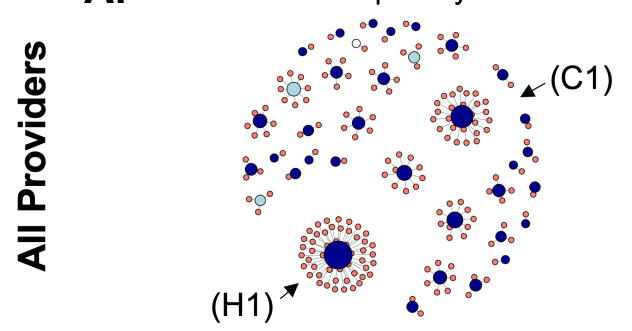

D.

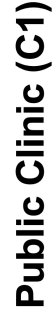

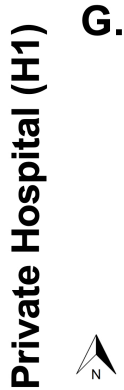

$(\mathrm{C} 1)$

A

H.
B.

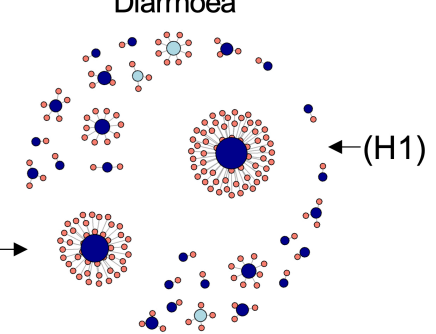

\section{Health Events (Behaviors)}

C.

(C1)

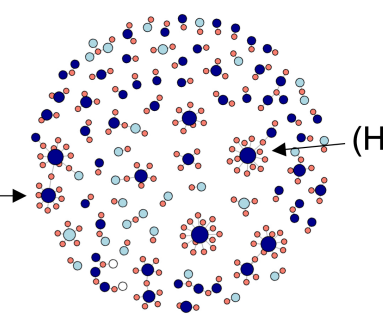

F.
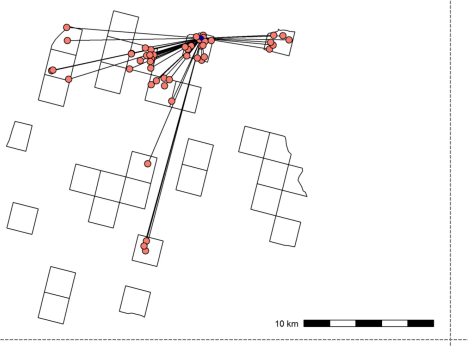

A

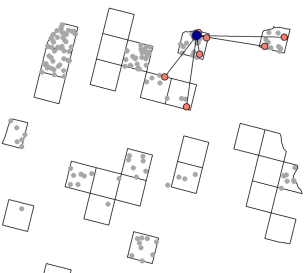

I.

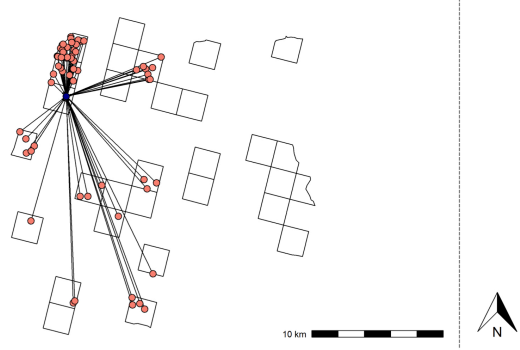

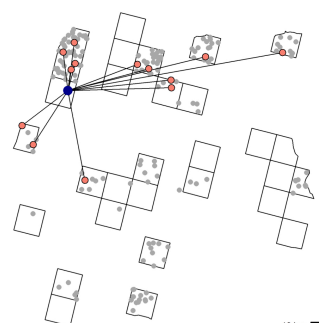


A.

B.

Figure 3

\section{Household}

Provider [Conventional]

Hospital

[Conventional]
Provider [Non-Conventional]
Provider

[Conventional]
Household

Provider

[Non-Conventional]

Hospital

[Conventional] 
medRxiv preprint doi: https://doi.org/10.1101/2020.12.03.20243394; this version posted May 7, 2021. The copyright holder for this preprint (which was not certified by peer review) is the author/funder, who has granted medRxiv a license to display the preprint in perpetuity. It is made available under a CC-BY-NC-ND 4.0 International license .

\section{TABLES}

\begin{tabular}{lcccc}
\hline Table 1. Household characteristics & \multicolumn{5}{c}{} \\
\hline Grid cell density & All & Low & Medium & High \\
& $\mathrm{N}=568$ & $\mathrm{n}=112$ & $\mathrm{n}=144$ & $\mathrm{n}=312$ \\
\hline Household members: (n\%) & & & & \\
0 to 1 years & $322(11)$ & $63(11)$ & $79(11)$ & $180(11)$ \\
2 to 4 years & $436(15)$ & $76(14)$ & $115(16)$ & $245(15)$ \\
5 to 10 years & $440(15)$ & $78(14)$ & $106(15)$ & $256(16)$ \\
11 to 20 years & $481(17)$ & $89(16)$ & $141(19)$ & $251(16)$ \\
$\geq 21$ years & $1221(42)$ & $253(45)$ & $284(39)$ & $684(42)$ \\
Total members & 2900 & $559(19)$ & $725(25)$ & $1616(56)$ \\
Highest-education level (HoH): $\mathrm{n}(\%)$ & & & & \\
None & $89(16)$ & $26(23)$ & $38(26)$ & $25(8)$ \\
Below secondary & $247(43)$ & $42(38)$ & $62(43)$ & $143(46)$ \\
Secondary and above & $232(41)$ & $44(39)$ & $23(31)$ & $144(46)$ \\
Transportation: $\mathrm{n}(\%)$ & & & & \\
Informal (foot/ bike/ donkey) & $176(31)$ & $52(46)$ & $64(44)$ & $60(19)$ \\
Public & $74(13)$ & $0(0)$ & $1(1)$ & $73(23)$ \\
Motorcycle taxi & $295(52)$ & $55(49)$ & $78(54)$ & $162(52)$ \\
Private car/ motorcycle & $19(3)$ & $2(2)$ & $1(1)$ & $16(5)$ \\
Primary source of income: $\mathrm{n}(\%)$ & & & & \\
Agriculture/ Animal husbandry & $266(47)$ & $92(82)$ & $105(73)$ & $69(22)$ \\
Vendor (Commerce) & $165(29)$ & $11(10)$ & $24(17)$ & $130(42)$ \\
Tradesperson & $61(11)$ & $5(4)$ & $7(5)$ & $49(16)$ \\
Salaried employment & $35(6)$ & $2(2)$ & $2(1)$ & $31(10)$ \\
None & $11(2)$ & $0(0)$ & $1(1)$ & $10(3)$ \\
Other & $30(5)$ & $2(2)$ & $5(3)$ & $23(7)$ \\
S.E.S indexa: $\mathrm{n}(\%)$ & 116 & $59(53)$ & $53(37)$ & $4(1)$ \\
First quintile & 112 & $29(26)$ & $40(28)$ & $43(14)$ \\
Second quintile & 113 & $20(18)$ & $34(24)$ & $59(19)$ \\
Third quintile & 115 & $2(2)$ & $12(8)$ & $101(32)$ \\
Fourth quintile & 112 & $2(2)$ & $5(3)$ & $105(34)$ \\
Fifth quintile & & &
\end{tabular}


medRxiv preprint doi: https://doi.org/10.1101/2020.12.03.20243394; this version posted May 7, 2021. The copyright holder for this preprint (which was not certified by peer review) is the author/funder, who has granted medRxiv a license to display the preprint in perpetuity.

It is made available under a CC-BY-NC-ND 4.0 International license .

\begin{tabular}{lcccc}
\hline Table 2. Health event characteristics & & & & \\
\hline Grid cell density & All & Low & Medium & High \\
& $\mathrm{N}=636$ & $\mathrm{n}=122(19)$ & $\mathrm{n}=136(21)$ & $\mathrm{n}=378(59)$ \\
\hline Patient age: $\mathrm{n}(\%)$ & & & & \\
0-4 years & $411(65)$ & $78(64)$ & $96(71)$ & $237(63)$ \\
5-10 years & $26(4)$ & $3(2)$ & $8(6)$ & $15(4)$ \\
11+ years & $199(31)$ & $41(34)$ & $32(24)$ & $126(33)$ \\
Symptom a: $\mathrm{n}(\%)$ & & & & \\
Congestion (cold) & $385(61)$ & $82(67)$ & $92(68)$ & $211(56)$ \\
Fever & $330(52)$ & $60(49)$ & $73(54)$ & $197(52)$ \\
Cough & $313(49)$ & $66(54)$ & $79(58)$ & $168(44)$ \\
Diarrhoea & $133(21)$ & $23(19)$ & $36(26)$ & $74(20)$ \\
Headache & $66(10)$ & $14(11)$ & $10(7)$ & $42(11)$ \\
Abdominal pain & $39(6)$ & $7(6)$ & $9(7)$ & $23(6)$ \\
Vomiting & $31(5)$ & $4(3)$ & $8(6)$ & $19(5)$ \\
Chest pain & $22(3)$ & $6(5)$ & $7(5)$ & $9(2)$ \\
Skin problem & $16(3)$ & $3(2)$ & $4(3)$ & $9(2)$ \\
Infection & $10(2)$ & $2(2)$ & $0(0)$ & $8(2)$ \\
Other symptoms ${ }^{2}$ & $80(13)$ & $12(10)$ & $14(10)$ & $54(14)$ \\
Cause (perceived): $\mathrm{n}(\%)$ & & & & \\
Temperature exposure & $258(41)$ & $52(43)$ & $59(43)$ & $147(39)$ \\
Medical/ epidemiological/ environmental & $130(20)$ & $16(13)$ & $26(19)$ & $88(23)$ \\
Cultural (e.g. teething) & $56(9)$ & $10(8)$ & $14(10)$ & $32(8)$ \\
Stress/ fatigue & $45(7)$ & $9(7)$ & $11(8)$ & $25(7)$ \\
Unknown & $136(21)$ & $31(25)$ & $26(19)$ & $79(21)$ \\
Severity (perceived): $\mathrm{n}(\%)$ & $382(60)$ & $66(55)$ & $85(63)$ & $231(61)$ \\
Not severe & $252(40)$ & $55(45)$ & $51(38)$ & $146(39)$ \\
Severe & $220(35)$ & $39(32)$ & $33(24)$ & $148(39)$ \\
Sought care: $\mathrm{n}(\%)$ & $416(65)$ & $83(68)$ & $103(76)$ & $230(61)$ \\
Yes & & &
\end{tabular}

a Percentage of health events that include listed symptoms; median symptoms/health event $=2$.

b 'Other' included anemia, back, diabetes, ear, hypertension, joint, mouth, pregnancy, seizure, throat, 381 trauma, vaginal and vision medical problems.

${ }^{c} \mathrm{~A}$ perceived imbalance of 'hot' and 'cold' within the body caused by environmental exposures (humoral 383 pathology). 
Table 3. Determinants to seek care for health events

\begin{tabular}{|c|c|c|c|c|c|c|}
\hline & $\begin{array}{l}\text { Care sought } \\
\mathrm{n}=220\end{array}$ & $\begin{array}{c}\text { Care not sought } \\
n=416\end{array}$ & $\mathrm{OR}(\mathrm{Cl})$ & $p$ value & $\mathrm{aOR}(\mathrm{Cl})$ & $p$ value \\
\hline \multicolumn{7}{|l|}{ Patient age: $\mathrm{n}(\%)$} \\
\hline $0-4$ years & $131(60)$ & $280(67)$ & $0.71(0.51-1.00)$ & 0.052 & Ref & Ref \\
\hline $5-10$ years & $10(5)$ & $16(4)$ & $1.19(0.53-2.67)$ & 0.672 & $0.77(0.22-2.63)$ & 0.675 \\
\hline $11+$ years & $79(36)$ & 119 (29) & $1.38(0.98-1.96)$ & 0.068 & $0.75(0.40-1.38)$ & 0.355 \\
\hline \multicolumn{7}{|l|}{ Illness ${ }^{\mathrm{a}}: \mathrm{n}(\%)$} \\
\hline Respiratory & $96(44)$ & $222(53)$ & $0.67(0.48-0.94)$ & 0.018 & $0.75(0.40-1.42)$ & 0.378 \\
\hline Diarrhoea & $17(8)$ & $35(8)$ & $0.91(0.50-1.66)$ & 0.757 & $0.69(0.27-1.73)$ & 0.426 \\
\hline Respiratory and diarrhoea & 19 (9) & $62(15)$ & $0.54(0.31-0.93)$ & 0.025 & $0.99(0.37-2.65)$ & 0.980 \\
\hline Other & $88(40)$ & $96(23)$ & $2.22(1.56-3.15)$ & $<0.001$ & Ref & Ref \\
\hline Distance $(\mathrm{km})^{\mathrm{b}}$ : median (IQR) & $3.2(1.3-5.5)$ & $3.5(1.5-6.1)$ & $0.97(0.93-1.02)$ & 0.239 & $0.96(0.91-1.01)$ & 0.135 \\
\hline \multicolumn{7}{|l|}{ Severity (perceived): $n(\%)$} \\
\hline Not-Severe & $92(42)$ & $290(70)$ & Ref & Ref & Ref & Ref \\
\hline Severe & $127(58)$ & $125(30)$ & $3.20(2.28-4.50)$ & $<0.001$ & $3.17(1.99-5.05)$ & $<0.001$ \\
\hline \multicolumn{7}{|l|}{ Time of health event ${ }^{\mathrm{c}}$} \\
\hline Day & $101(48)$ & $138(36)$ & Ref & Ref & Ref & Ref \\
\hline Night & $108(52)$ & $242(64)$ & $0.69(0.50-0.96)$ & 0.029 & $0.80(0.49-1.29)$ & 0.359 \\
\hline \multicolumn{7}{|l|}{ Transportation: $\mathrm{n}(\%)$} \\
\hline Informal (foot/ bike/ donkey) & $43(20)$ & $130(31)$ & $0.53(0.36-0.79)$ & 0.002 & $0.78(0.28-2.19)$ & 0.638 \\
\hline Public/ motorcycle taxi & $166(76)$ & $267(64)$ & $1.72(1.19-2.49)$ & 0.004 & Ref & Ref \\
\hline Private car/ motorcycle & $10(5)$ & $17(4)$ & $1.12(0.50-2.48)$ & 0.785 & $0.49(0.15-1.58)$ & 0.235 \\
\hline \multicolumn{7}{|l|}{ Highest-education level $(\mathrm{HoH}): \mathrm{n}(\%)$} \\
\hline None & $22(10)$ & $66(16)$ & $0.59(0.35-0.98)$ & 0.043 & Ref & Ref \\
\hline Below secondary & $88(40)$ & $181(44)$ & $0.87(0.62-1.21)$ & 0.394 & $1.34(0.60-3.02)$ & 0.475 \\
\hline Secondary and above & $110(50$ & $169(41)$ & $1.46(1.05-2.03)$ & 0.024 & $1.61(0.68-3.77)$ & 0.277 \\
\hline \multicolumn{7}{|l|}{ Primary source of income $n(\%)$} \\
\hline Agriculture/Animal husbandry & $87(43)$ & $182(48)$ & $0.85(0.61-1.20)$ & 0.364 & $5.04(0.57-44.51)$ & 0.146 \\
\hline Vendor (Commerce) & $71(35)$ & $134(35)$ & $1.02(0.72-1.46)$ & 0.897 & $2.56(0.29-22.67)$ & 0.398 \\
\hline Tradesperson & 33 (16) & $47(12)$ & $1.41(0.87-2.29)$ & 0.160 & $2.68(0.29-25.18)$ & 0.388 \\
\hline Salaried employment & $16(8)$ & $25(6)$ & $1.24(0.65-2.38)$ & 0.512 & $2.95(0.30-28.67)$ & 0.351 \\
\hline \multicolumn{7}{|l|}{ Grid cell population density: $n(\%)$} \\
\hline Low & $84(32)$ & $39(10)$ & $0.86(0.57-1.32)$ & 0.498 & Ref & Ref \\
\hline Medium & $33(12)$ & $103(28)$ & $0.54(0.35-0.83)$ & 0.005 & $1.11(0.52-2.35)$ & 0.783 \\
\hline High & $148(56)$ & $230(62)$ & $1.66(1.18-2.34)$ & 0.004 & $1.69(0.82-3.47)$ & 0.154 \\
\hline $\begin{array}{l}\text { Health events per prior month: } \\
\text { median (IQR) }\end{array}$ & $1(1-2)$ & $1(1-2)$ & $1.08(0.88-1.32)$ & 0.458 & $0.94(0.72-1.23)$ & 0.666 \\
\hline S.E.S index ${ }^{d}$ median (IQR) & $3(2-4)$ & $3(2-4)$ & $1.45(1.03-2.03)$ & 0.034 & (omitted) & (omitted) \\
\hline
\end{tabular}




\section{$6 \quad$ Footnote for Table 3}

7 a Respiratory is defined as 'cough' or 'cold' with fever and no diarrhoea, diarrhoea is with or 8 without blood in the stool and no respiratory infection, 'other' included anemia, back, diabetes, ear, 9 hypertension, joint, mouth, pregnancy, seizure, throat, trauma, vaginal and vision medical problems.

$0 \quad{ }^{b}$ Calculated using straight-line distance between a house and the chosen provider for

1 respiratory standardized case.

2 ' Day is between 6AM- 6PM and night is between 6PM-6AM.

3 d See methods for variables included in the S.E.S index 
medRxiv preprint doi: https://doi.org/10.1101/2020.12.03.20243394; this version posted May 7, 2021. The copyright holder for this preprint

(which was not certified by peer review) is the author/funder, who has granted medRxiv a license to display the preprint in perpetuity. It is made available under a CC-BY-NC-ND 4.0 International license .

\section{REFERENCES}

1. Programme UND. Sustainable Development Goals: @undp; 2020 [Available from: https://www.undp.org/content/undp/en/home/sustainable-development-goals.html accessed March 202020.

2. Measuring Progress From 1990 to 2017 and Projecting Attainment to 2030 of the Health-Related Sustainable Development Goals for 195 Countries and Territories: A Systematic Analysis for the Global Burden of Disease Study 2017. Lancet (London, England) 2018;392(10159) doi: 10.1016/S0140-6736(18)322815

3. The World Health Organization, The World Bank. Tracking Universal Health Coverage: 2017 Global Monitoring Report. Washington, D.C., 2017.

4. Amouzou A, Jiwani SS, da Silva ICM, et al. Closing the inequality gaps in reproductive, maternal, newborn and child health coverage: slow and fast progressors. BMJ Global Health 2020;5(1):e002230. doi: 10.1136/bmjgh-2019002230

5. Roberton T, Carter ED, Chou VB, et al. Early estimates of the indirect effects of the COVID-19 pandemic on maternal and child mortality in low-income and middleincome countries: a modelling study. The Lancet Global Health 2020 doi: https://doi.org/10.1016/S2214-109X(20)30229-1

6. Poverty and Access to Health Care in Developing Countries - Peters - 2008 - Annals of the New York Academy of Sciences - Wiley Online Library. 2020 doi: 10.1196/annals.1425.011

7. Do M, Babalola S, Awantang G, et al. Associations between malaria-related ideational factors and care-seeking behavior for fever among children under five in Mali, Nigeria, and Madagascar. PLOS ONE 2018;13(1):e0191079. doi: 10.1371/journal.pone.0191079

8. Manna B, Nasrin D, Kanungo S, et al. Determinants of Health Care Seeking for Diarrheal Illness in Young Children in Urban Slums of Kolkata, India. The American journal of tropical medicine and hygiene 2013;89(1 Suppl) doi: 10.4269/ajtmh.12-0756

9. D'Souza RM. Role of health-seeking behaviour in child mortality in the slums of Karachi, Pakistan. Journal of Biosocial Science 2003;35(1):131-44. doi: http://dx.doi.org/10.1017/S0021932003001317

10. Amuyunzu-Nyamongo M, Nyamongo I. Health Seeking Behaviour of Mothers of Under-Five-Year-Old Children in the Slum Communities of Nairobi, Kenya. Anthropology \& Medicine 2006;13(1):25-40. doi: 10.1080/13648470500516261

11. Kolola T, Gezahegn T, Addisie M. Health Care Seeking Behavior for Common Childhood Illnesses in Jeldu District, Oromia Regional State, Ethiopia. PLOS ONE 2016;11(10):e0164534. doi: 10.1371/journal.pone.0164534 
medRxiv preprint doi: https://doi.org/10.1101/2020.12.03.20243394; this version posted May 7, 2021. The copyright holder for this preprint

(which was not certified by peer review) is the author/funder, who has granted medRxiv a license to display the preprint in perpetuity. It is made available under a CC-BY-NC-ND 4.0 International license .

12. Sarker AR, Sultana M, Mahumud RA, et al. Prevalence and Health Care-Seeking Behavior for Childhood Diarrheal Disease in Bangladesh. Glob Pediatr Health 2016;3 doi: 10.1177/2333794x16680901

13. Ismail SA, McCullough A, Guo S, et al. Gender-related differences in care-seeking behaviour for newborns: a systematic review of the evidence in South Asia. BMJ Global Health 2019 doi: 10.1136/bmjgh-2018-001309

14. Sultana M, Sarker AR, Sheikh N, et al. Prevalence, determinants and health careseeking behavior of childhood acute respiratory tract infections in Bangladesh. PLOS ONE 2019;14(1):e0210433. doi: 10.1371/journal.pone.0210433

15. Wambui WM, Kimani S, Odhiambo E. Determinants of Health Seeking Behavior among Caregivers of Infants Admitted with Acute Childhood Illnesses at Kenyatta National Hospital, Nairobi, Kenya. Int J Pediatr 2018;2018 doi: 10.1155/2018/5190287

16. Akinyemi JO, Banda P, Wet ND, et al. Household relationships and healthcare seeking behaviour for common childhood illnesses in sub-Saharan Africa: a cross-national mixed effects analysis. BMC Health Services Research 2019;19(1):1-11. doi: doi:10.1186/s12913-019-4142-x

17. Ellis AA, Winch $P$, Daou Z, et al. Home management of childhood diarrhoea in southern Mali-Implications for the introduction of zinc treatment. Social Science \& Medicine 2007;64(3):701-12. doi: https://doi.org/10.1016/j.socscimed.2006.10.011

18. Rutebemberwa E, Nsabagasani X, Pariyo G, et al. Use of drugs, perceived drug efficacy and preferred providers for febrile children: implications for home management of fever. Malaria Journal 2009;8(1):1-10. doi: doi:10.1186/14752875-8-131

19. Tsukahara $T$, Sugahara $T$, Ogura $S$, et al. Effect of pecuniary costs and time costs on choice of healthcare providers among caregivers of febrile children in rural Papua New Guinea. Health Econ Rev 2019;9 doi: 10.1186/s13561-019-0250-x 20. M A-N, IK N. Health Seeking Behaviour of Mothers of Under-Five-Year-Old Children in the Slum Communities of Nairobi, Kenya. Anthropology \& Medicine 2006;13(1):25-40. doi: 10.1080/13648470500516261

21. Cross J, MacGregor HN. Knowledge, legitimacy and economic practice in informal markets for medicine: A critical review of research. Social Science \& Medicine 2010;71(9):1593-600. doi: https://doi.org/10.1016/j.socscimed.2010.07.040

22. Peters DH, Bloom G. Bring order to unregulated health markets. Nature 2012;487(7406):163-65. doi: 10.1038/487163a

23. Yao J, Agadjanian V. Bypassing health facilities in rural Mozambique: spatial, institutional, and individual determinants. BMC Health Services Research 2018;18(1):1006. doi: 10.1186/s12913-018-3834-y 
medRxiv preprint doi: https://doi.org/10.1101/2020.12.03.20243394; this version posted May 7, 2021. The copyright holder for this preprint

(which was not certified by peer review) is the author/funder, who has granted medRxiv a license to display the preprint in perpetuity. It is made available under a CC-BY-NC-ND 4.0 International license .

24. Rao KD, Sheffel A. Quality of clinical care and bypassing of primary health centers in India. Social Science \& Medicine 2018;207:80-88. doi: https://doi.org/10.1016/j.socscimed.2018.04.040

25. Mackintosh M, Channon A, Karan A, et al. What is the private sector? Understanding private provision in the health systems of low-income and middleincome countries. The Lancet 2016;388(10044):596-605. doi: 10.1016/S01406736(16)00342-1

26. Durham J, Marcos M, Hill PS, et al. Haïti and the health marketplace: the role of the private, informal market in filling the gaps left by the state. BMC Health Services Research 2015;15(1):1-10. doi: doi:10.1186/s12913-015-1088-5

27. World Health Organization, United Nations Children's Fund (UNICEF). A vision for primary health care in the 21st century: towards universal health coverage and the Sustainable Development Goals 2018 [Available from: https://apps.who.int/iris/bitstream/handle/10665/328065/WHO-HIS-SDS-2018.15eng.pdf?sequence=1\&isAllowed=y accessed September 282020.

28. Geldsetzer P, Williams TC, Kirolos A, et al. The Recognition of and Care Seeking Behaviour for Childhood Illness in Developing Countries: A Systematic Review. PLOS ONE 2014;9(4):e93427. doi: 10.1371/journal.pone.0093427

29. Colvin C, Smith H, Swartz A, et al. Understanding Careseeking for Child Illness in sub-Saharan Africa: A Systematic Review and Conceptual Framework Based on Qualitative Research of Household Recognition and Response to Child Diarrhoea, Pneumonia and Malaria. Social science \& medicine 2013;86 doi: 10.1016/j.socscimed.2013.02.031

30. McPake B, Hanson K. Managing the public-private mix to achieve universal health coverage. The Lancet 2016;388(10044):622-30. doi: https://doi.org/10.1016/S0140-6736(16)00344-5

31. Bennett S, Bloom G, Knezovich J, et al. The future of health markets. Global Health 2014;10:51. doi: 10.1186/1744-8603-10-51

32. Durham J, Michael M, Hill PS, et al. Haiiti and the health marketplace: the role of the private, informal market in filling the gaps left by the state. BMC Health Services Research 2015;15(1):1-10. doi: doi:10.1186/s12913-015-1088-5

33. Gage AD, Leslie HH, Bitton A, et al. Assessing the quality of primary care in Haiti. Bull World Health Organ 2017;95(3):182-90. doi: 10.2471/blt.16.179846

34. Moise K, Bernard JJ, Henrys JH. Evaluation of antibiotic self-medication among outpatients of the state university hospital of Port-Au-Prince, Haiti: a crosssectional study. Pan Afr Med J 2017;28 doi: 10.11604/pamj.2017.28.4.12589

35. Hill PS, Pavignani E, Michael M, et al. The "empty void" is a crowded space: health service provision at the margins of fragile and conflict affected states. Conflict and Health 2014;8(1):1-10. doi: doi:10.1186/1752-1505-8-20 
medRxiv preprint doi: https://doi.org/10.1101/2020.12.03.20243394; this version posted May 7, 2021. The copyright holder for this preprint

(which was not certified by peer review) is the author/funder, who has granted medRxiv a license to display the preprint in perpetuity. It is made available under a CC-BY-NC-ND 4.0 International license .

36. Kohler JC, Pavignani E, Michael M, et al. An examination of pharmaceutical systems in severely disrupted countries. BMC International Health and Human Rights 2012;12(1):1-11. doi: doi:10.1186/1472-698X-12-34

37. Clark H, Coll-Seck AM, Banerjee A, et al. A future for the world's children? A WHOUNICEF-Lancet Commission. The Lancet 2020;395(10224):605-58. doi: 10.1016/S0140-6736(19)32540-1

38. United Nations Interagency Group for Child Mortality Estimation. Levels and Trends in Child Mortality. New York

United Nations Children's Fund, 2017.

39. Wagenaar BH, Kohrt BA, Hagaman AK, et al. Determinants of Care Seeking for Mental Health Problems in Rural Haiti: Culture, Cost, or Competency. https://doiorg/101176/appips201200272 2013 doi: 10.1176/appi.ps.201200272 40. White K, Small M, Frederic R, et al. Health Seeking Behavior Among Pregnant Women in Rural Haiti. Health care for women international 2006;27(9) doi: 10.1080/07399330600880384

41. Raymondville M, Rodriguez CA, Richterman A, et al. Barriers and facilitators influencing facility-based childbirth in rural Haiti: a mixed method study with a convergent design. BMJ Global Health 2020;5(8):e002526. doi: 10.1136/bmjgh2020-002526

42. Cros M, Cavagnero E, Alfred JP, et al. Equitable realization of the right to health in Haiti: how household data inform health seeking behavior and financial risk protection. International Journal for Equity in Health 2019;18(1):1-16. doi: doi:10.1186/s12939-019-0973-7

43. Ponsar F, Tayler-Smith K, Philips M, et al. No Cash, No Care: How User Fees Endanger Health--Lessons Learnt Regarding Financial Barriers to Healthcare Services in Burundi, Sierra Leone, Democratic Republic of Congo, Chad, Haiti and Mali. International health 2011;3(2) doi: 10.1016/j.inhe.2011.01.002

44. Borgatti SP, Martin GJohnson, Jeffrey C. Analyzing Social Networks: SAGE Publications Ltd 2018.

45. Davis A, Gardner BB, Gardner MR, et al. Deep South; a social anthropological study of caste and class. Chicago, III.: The University of Chicago Press 1941.

46. Vacca R, Solano G, Lubbers M, et al. A Personal Network Approach to the Study of Immigrant Structural Assimilation and Transnationalism. Social Networks 2018;53:72-89. doi: 10.1016/j.socnet.2016.08.007

47. Team RC. R: A language and environment for statistical computing: R Foundation for Statistical Computing, Vienna, Austria; 2014 [Available from: http://www.Rproject.org/.

48. Pebesma E, Bivand R. Simple Features for R. R package version 0.6-3. 2018

49. World Health Organization, Pan American Health Organization. Culture and Mental Health in Haiti: A Literature Review, 2010. 